International Journal of English Literature and Social Sciences
Vol-6, Issue-4; Jul-Aug, 2021

Peer-Reviewed Journal

\title{
Arjun Reddy (2017): Momentous or Misguided Misogyny?
}

\author{
Ms. Shubhangi Bhatnagar
}

Department of English Literature, IIS University, Jaipur, India

Received: 15 Jul 2021; Received in revised form: 13 Aug 2021; Accepted: 23 Aug 2021; Available online: 31 Aug 2021

C2021 The Author(s). Published by Infogain Publication. This is an open access article under the CC BY license

(https://creativecommons.org/licenses/by/4.0/).

\begin{abstract}
Sandeep Vanga's Arjun Reddy (2017) was revered for its unflinching story-telling, unprecedented cinematography and rousing music. The film won accolades from both, the critics and audience, alike for doing away with the tropes of toxic masculinity and misogyny in South Asian cinema. The film revolves around the eponymous hero, Arjun Reddy, and his intense and raw painful suffering for love. The research paper will question how successful the film was in its attempt to portray Arjun Reddy as a flawed, complex character by depicting anger as his only fatal flaw, while also granting him Herculean powers, captivating looks and prodigal skills as a surgeon and an all-rounder, as well as, simultaneously claiming to be audaciously real. The definitions of masculinity, as presented in the film, are analysed and challenged. The study will also question the power dynamics of Arjun and Preeti's relationship, and Arjun's treatment of women, in general. Feminist concerns in film theory such as 'The Male Gaze' and the issue of gender representation shall be discussed. 'Did the film do more damage than good with its thinly veiled misogyny presented as new-age feminism?' are some of the important arguments that will be resolved.
\end{abstract}

Keywords-Arjun Reddy, feminism, misogyny, patriarchy, South-Asian cinema, toxic-masculinity.

\section{INTRODUCTION}

Written and directed by Sandeep Vanga, Arjun Reddy (2017) was heralded as a new path-breaking chapter in Telugu cinema. Revered for its unflinching story-telling, unprecedented cinematography and rousing music, the film won accolades from both, the critics and audience, alike. The film revolves around the eponymous hero, Arjun Reddy, and his intense and raw painful suffering for love. The protagonist is a high-functioning alcoholic surgeon who has anger management issues. Arjun is on a self-destructive path after his girlfriend, Preeti Shetty, gets married; the film focuses on his downfall and subsequent resurgence. The film was labelled radical for its candid treatment of sexuality, without the sleazy gaze of voyeurism. Some have even gone on to say that the film is a feminist masterpiece for its titular protagonist's portrayal.

The film has been called a breath of fresh air for its flawed depiction of the hero, and the heroine enthusiastically engaging in pre-marital sexual relations. Arjun is praised for his 'bold choice' of accepting his married girlfriend, when he finds her pregnant. He opens his arms up to her, claiming to know that she is not happy with her husband. His generosity, of accepting a woman touched by another man is rewarded when Preeti happily announces that she is, in fact, pregnant with his child, not having let her husband 'lay even a little finger on her'. The film ties a neat bow with a happy ending to their intensely turbulent relationship. While on its way to mark the dawn of a new era in Telugu cinema, the film points to several red flags in its definition of being liberal and progressive.

The research paper will question how successful the film was in its attempt to portray Arjun Reddy as a flawed, complex character by depicting anger as his only fatal flaw, while also granting him Herculean powers, captivating looks and prodigal skills as a surgeon and an all-rounder, as well as, simultaneously claiming to be audaciously real. The definitions of masculinity, as presented in the film, are analysed and challenged. The study will also question the power dynamics of Arjun and 
Preeti's relationship, and Arjun's treatment of women, in general.

\section{THE HERO OF MANY PARADOXES}

Arjun Reddy was declared a trailblazer by the critics, in terms of its portrayal of the hero. Telugu cinema's protagonists have been marked with larger-than-life superhuman elements. The critics claim that a new chapter for the Telugu hero has arrived with Arjun Reddy, who is deeply flawed and a complex character. With a wellrounded protagonist, the critics appreciate the film-makers for their lack of hero-worship. Arjun Reddy is presented to the audience as a disturbingly real and a naturally impassioned hero. The attempt was received well with the audience, many claiming the hero to be quite relatable. It was refreshing for the crowds to see a hero brazenly struggle with extreme anger issues and addiction. The film's biggest achievement seems to be its choice of a hero who's not infallible, by granting him a fatal flaw: anger. What seems interesting here is that while the film grants it's hero a single fatal flaw, it over-compensates with a slew of positive traits.

A gifted athlete with Herculean powers, Arjun's physical strength cannot be matched by any other male throughout the film. We witness him being an impeccable football player, and then bashing his jealous opponents with equal ease. The physical strength is complimented by his extreme good-looks. Even at his shabbiest, most unfit state, Arjun remains a heart-throb among women. His most celebrated talent of all turns out to be his acumen as a surgeon. From his days as a college topper, to a workaholic surgeon, he proves that his skills are prodigal. In fact, he can perform surgeries with ease and precision, even while being drunk. He is revered by all, from his cultlike following in college days, to his team of nurses and his patients, despite all his flaws. Additionally, he is also blessed to be born in a reputable, wealthy family that can support the impulsive decisions rising out of his uncontrollable anger. His fatal flaw that is supposed to humanize him is also fetishized throughout the film as his free-spiritedness and a devil-may-care attitude. The supposed audaciously real hero, that the film claims to represent, resembles a superhuman who is a far-cry from an average man. Hurling abuses, and consuming drug and alcohol is not enough for him to become relatable.

As mentioned earlier, his fatal flaw itself is fetishized in the film. Whenever the hero lands up in a problem due to his lack of anger management, the audience never truly charges him guilty of his faults. In fact, a genuine sympathy arises for Arjun from the audience, who are duped into believing that the hero is a victim of the situation, rather than the perpetrator. This image is aided by the fact that Arjun is never ashamed to own up to his mistakes. While the film wants to portray his honesty as the integrity of his character, it often borders to shamelessness. But what truly amounts to his image as an ultimate victim, are the circumstances. The plot carefully constructs these situations in a manner that Arjun is only seen retaliating to forces that are already at play against him. This always puts the hero in a situation of defense, more than offense.

In one of the initial scenes where the hero is being introduced to us, an angry Arjun tries to force himself on a woman at knife-point, who refuses to engage in any sexual activity when she realizes that her fiancé is at the door. Before Arjun can do something truly deprave, at the exact moment, power comes back on, making him aware of his actions. He leaves the woman be, but not without exposing her affair to her fiancé. Not only does the hero become redeemable in the moment, by a chance of luck that proves him to be a moral man, the audience is soon made aware of his past. The excruciating pain of having lost his true love makes his actions justifiable. The scene also makes sure that this woman, who denies the hero sex, has connotations of a fallen woman attached to her. The audience eventually gains more sympathy for the heartbroken hero, than a woman who is cheating on her lovestruck fiancé. Another such scene happens on the football ground, where Arjun's team is leading over the opponents with a huge margin. We see that the losing team tries to rile Arjun up in order to get him disqualified. Even the referee is biased towards the opposition. Arjun appears to be more mature when he doesn't react to these provocations, on the advice from his teammate. With all the odds against them, Arjun's team still manages to win, proving that they are clearly more deserving. It is then that one of the players from the opposition attacks Arjun, out of jealousy. When Arjun, consumed by anger, beats up the entire team, the audience remains faithful to Arjun. His anger becomes justified.

The biggest fall of the flawed, alcoholic hero comes when his license as a surgeon is revoked, because he overdoses during a surgery. While this is an issue of grave concern, and is clearly immoral, Arjun still manages to garner the sympathy of the audience, rather than their disappointment. All the factors lead the audience to believe that Arjun is only a victim of his circumstance. First of all, the surgery goes well and the patient remains unharmed. Without any real consequence, it is easy for everyone to move-on. The hospital clearly stands in the wrong in this situation, because they didn't have any surgeons on call during Arjun's day-off. He is pleaded by his nurses to attend to the emergency, even though he 
reveals that he is highly intoxicated and has no motor control, because they believe he is the best. In fact, he regularly operates on patients while being drunk, in moderation. The workaholic surgeon proves to be better than most, even while being intoxicated, and performs more surgeries than anybody else. It is the hospital's manager, who holds a grudge against Arjun, and decides to make it his personal agenda to have him penalized. This threat cannot be pursued because the hospital stands clearly in the wrong, and can be penalized instead for not recording most of Arjun's surgeries out of their greed and corruption. To add to this, Arjun's integrity as a surgeon is backed by hundreds of testimonials from his patients and nurses. Even the Dean of his previous college vouches for his brilliant skills as a surgeon. It is only due to his own morality, that he could not lie to the law about being intoxicated, resulting in his license being revoked. This is a prime example of how no matter how grave a situation Arjun finds himself in due to his flaws, yet is never truly shown to be guilty. While trying to build their hero as a grey character, the film ultimately always portrays Arjun in the white, and his opposition in black. This makes it difficult for the audience to hold him responsible for his misgivings.

Apart from having a flawed hero, the film was celebrated for having a hero who embraced his tears and vulnerability, without becoming a laughing stock or losing his manhood. Critics have appreciated the film for not using tears as a symbol of weakness, but of anguish. Tears are not the only emblem of vulnerability; it is also the depiction of Arjun's helplessness in the face of addiction. Yet, the entire discussion of showing a hero cry on screen is squashed by a single line where his best friends asks a crying Arjun, "Do boys cry like that?". Further to negate such claims, every time the hero is shown to be vulnerable, he emerges out of the situation as an alpha male. One of the first examples of this irony is when the Dean of the college summons Arjun after his brawl during the football match. The Dean begins by mentioning that Arjun is the most brilliant student the college has seen in years, and is applauded for this by the students. He then adds that even though Arjun's a brilliant student, he lacks anger management skills; and the behaviour of a student is much more important to him than their academics. He gives Arjun a choice to either put an apology letter on the notice board by the end of the day, or he would be suspended by the college. Arjun refuses to apologize and decides to leave the college on his own terms, but not without making the Dean realize that he is just a mere employee of the college and the college needs Arjun more than he needs the college. The scene is set up in a way that it only puts the hero on a pedestal, by having his numerous achievements overshadow his misbehaviour. Rather than seeming vulnerable, Arjun instead emerges at the top. A similar pattern is followed when Arjun is seemingly at his lowest, and his friends try to help him. When his best friend, Shiva, reminds him that Preeti is now married, so he must take himself out of the rut and move-on, Arjun rather than heeding to the advice, instead belittles Shiva by reminding him that it is about time he did something with his career. Arjun rubs in the fact all their other friends, and Arjun himself being a surgeon, are all doing better than Shiva, who is still just running a clinic. His other friend, Kamal, decides to invite a heart-broken, lovelorn Arjun who had also recently gotten his license temporarily revoked, to his wedding. Arjun cruelly states that Kamal's love story can never be as pure and intense as his and Preeti's, hence he doesn't deserve to have a love marriage when Arjun can't. In both these situations, even though it's Arjun who is seemingly being portrayed in a rather vulnerable state, he never lets go of his position as the alpha male, no matter how worse the situations get in his life. He always seems to point out that he will always be better than the other, even at his worst. He is truly at his lowest only when he goes broke, and is pushed to the streets. Even then, the film cannot show the hero to be utterly helpless. A homeless man decides to help him out and pays for his necessities. Although it's Arjun who is utterly vulnerable at this stage, the homeless man doesn't act like a friend or an equal, and continues to be his inferior and serve him selflessly. Yet again, Arjun retains his position as an alpha male.

The most problematic claims that the film makes, and is appreciated for, is for having a feminist hero. Arjun Reddy supposedly defied the misogynistic ideals of the previous Telugu heroes with his own progressive ideals as a feminist. One of the instances that acts as a vehicle to this belief is the scene where his friend Shiva introduces him to his to-be brother-in-law. Arjun strongly and unabashedly objects to the derogatory statements made by his friend's future brother-in-law that objectified airhostesses. The scene itself becomes problematic when Arjun asks his friend whether he would allow such a man to marry his sister. The woman becomes a mere property being transferred from one man to the other. All agency is taken away from his sister when it is her brother's permission that becomes more important than her own consent. It proves that this was only a token scene for feminism, without the ideology being truly understood neither by the film-makers nor the hero. The film won accolades for having his hero make the 'bold' choice of accepting his girlfriend, who's already pregnant with other man's baby. This scene too becomes questionable when the hero is rewarded for his decision, when his girlfriend ultimately 
reveals that it is, in fact, his own baby. She further adds that she did not even let her husband, "lay even a little finger on her." The heroine has to be dragged back into the mould of a 'virtuous' woman, in order to make a happy ending that's acceptable to the audience. This comes as a sharp contrast to the hero himself, who becomes a sex addict in their time apart, in order to drown out pangs of separation and heart-break. His fidelity is never questioned, or becomes a point of discussion.

The supposedly feminist film is, in fact, full of sexist instances. The issue of consent is dealt with extremely poorly. Preeti is introduced to the audience through what Laura Mulvey called 'the male gaze'. Arjun is the active bearer of the look, while Preeti is not even given as much agency to even look at him. It is this instance when Arjun falls in love with her at first sight, and decides that she is going to be his girlfriend. Preeti, on the other hand, remains completely oblivious and passive.

What counts is what the heroine provokes, or rather what she represents. She is the one, or rather the love or fear she inspires in the hero, or else the concern he feels for her, who makes him act the way he does. In herself the woman has not the slightest importance. (Mulvey 4)

Arjun then threatens all the boys on campus to not get involved with, or subject Preeti to ragging, having claimed her his own. He adds that they free to do whatever they want with the other girls. He continues to neglect the need of Preeti's consent, and plants a kiss on her cheek during their very first conversation. Arjun goes on to select where she sits in the class, with whom, her friends and her roommate for her. In an extremely disturbing instance, Arjun decides that Preeti, a 'pretty' girl, should be friends with a 'fat' girl, since two pretty girls can never be friends, but "a pretty chick and a fat chick is a dynamic combination." This is also coming from a hero who is against objectification of women. He takes her out of the classroom on multiple occasions and in the guise of 'teaching' her anatomy, uses her body as a prop, and continues to disregard her consent. To add to the absurdity of the situation, Preeti remains passive while Arjun continues invades her personal space and agency. The entire college turns a side eye to such problematic behaviour. Preeti, eventually, does initiate a kiss and falls in love with him, only after being relentlessly pursued by him. The reason perhaps why this behaviour seems normal to people is, because when the hero is given god-like attributes (albeit with a fatal flaw), it almost seems impossible for a girl to not fall in love with him, or at least be attracted to him. Preeti is then assumed to be lucky, rather than a victim of harassment. Women throughout the film are only the property of men. When Arjun reveals to his friend that he is planning to 'take' Preeti back, even though she's pregnant, his friend points out that before her marriage Arjun had to take her father's permission and now he'll have to take her husband's. Even a minor character like his house maid, needs to bring her husband in order to vouch for her. Another emblem of misogyny in the film is the staggering amount of abuses used by the hero that are inherently misogynistic. These abuses directed towards women are used in order to make Arjun Reddy a more realistic and relatable character. Clearly, the film does more disservice in the name of feminism, than help the cause.

The film won accolades for the brilliant subtlety with which Vijay Deverakonda brings to life the poetic and heart-wrenching tragedy of the character. The audiences, as well as, the critics claim to be moved by his pangs of separation. For a character so heart-breakingly tragic that he destroys the cinematic construct of a hero, Arjun Reddy always manages to get a happy ending, or at least never completely pays his dues. This trend is established in the very beginning when Arjun is suspended from the college, only because he was instigated by the losing rival team. Arjun decides to leave the college on his own terms, making the Dean realize that they need him more than he needs them. But when he falls in love with Preeti at the first sight, he is conveniently able to make his way back into the college. So, the instance of him wrongly being suspended from the college, comes to an end with him finding the love of his life. When true tragedy strikes and Preeti gets married to another man, Arjun finds himself in the bottom of the pits. His family also decides to cut ties with him. He is seen drowning his sorrows in copious amounts of alcohol, drugs, work and sex. Even at this stage, Arjun remains the most skillful surgeon, who's revered by his nurses and patients. His friends loyally remain by his side; his disregard and disrespect towards them is all forgiven, considering that he is grieving. The substance abuse supposedly makes him less attractive, leaving him looking ungroomed and unfit. Yet, women find him undeniably attracted, so much so that, a leading actress falls head-overheels in love with him, even after being warned that their relationship is strictly physical.

With his license being temporarily revoked, his only source of sustenance snatched away from him. He spirals down to the very bottom and is forced to live on the streets. From being a celebrated medical student to being homeless man, the story is posed as an undeniable tragedy. Surprisingly, before he can even spend a day on the streets, his friend, Shiva, hunts him down. Although, Shiva comes bearing the dreadful news of his grandmother's demise, this eventually leads to a reconciliation with his family. The news brings him back to his senses and he decides to become sober. The misfortune of his license being temporarily revoked comes 
to an end with him regaining the love and acceptance of his family, living comfortably with financial security, and then going on a leisurely trip to Italy in order to relieve him off his stress. Before going on the trip, Arjun spots Preeti almost eight months pregnant in a park. He contemplates and decides that it's not too long and Preeti belongs to him. On his arrival, he finds Preeti and asks her to marry him. Eventually, after a little reluctance and getting his assurance that he will love her child like his own, Preeti accepts his proposal. His generosity of accepting a woman pregnant with someone else's child is rewarded when Preeti reveals that the child is, in fact, his own and she hadn't even let her husband "lay even a little finger on her." She further adds that she had been waiting for him all along but didn't contact him only because she thought he was in a relationship with the actress. For a tragic hero, Arjun manages to marry the love of his life, and their marriage is magically accepted by both their families. Preeti's father, who had earlier been vehemently against their relationship, claims that he was in the wrong to judge a relationship as "pure" as theirs, as something immoral. The only consequence he does pay is the temporary suspension of his license, but it remains doubtful whether a temporary suspension is enough for a mistake as grave as conducting surgery while being intoxicated, hundreds of times.

\section{THE MASTER-SLAVE RELATIONSHIP}

Romantic love is often accused of being an accomplice in men's traditional dominance over women in intimate relationships, "The scenario of romantic/non-romantic love in our culture and the social structures built around it constitute one of the main forces keeping women tied into traditional gender roles and subordinate to men" (Collins 205). The assumption is that women are taught that they should subordinate their own needs and interests to those of their partners. The partner and the relationship should come before self. And, at the same time, they are taught they should expect, and permit, men to act in a more selfinterested way. Conversely, men's standards for themselves are supposedly much less other-oriented than those they hold for women. The claim is that men believe they may always ask what is in it for them, and that such behaviour does not befit a woman in love. The concept of romance is "implicated in maintaining a cultural definition of the notion of love which is detrimental to women" (Jackson 50). This pattern is thought to lead women into acquiescent behaviour. The adorable college romance is what remains at the heart of Arjun Reddy. Critics have claimed that the love in the film is pure, unabashedly bold and hard-hitting. What seems like a narrative of selfless love is only a power struggle for dominance of one over the other. The traditional analysis of romantic love fits perfectly and explains the power dynamics of Arjun and Preeti's relationship, which skews heavily in Arjun's favour. They both adopt their traditional roles of masculine and feminine. While Arjun decides the terms of their relationship, Preeti remains acquiescent. Arjun decides almost every aspect of her life, while she simply adheres to his command. In fact, it is only half way through the film that we even hear Preeti speaking her mind. The film maintains a clear gendered imbalance.

Romantic love clearly remains a struggle of domination over the other. According to G.W.F. Hegel, domination contains the threat or the possibility of violence against the other. Violence could be of any nature: mental, psychological or physical. Violence is a way of expressing or asserting control over another, of establishing one's own self-boundary and negating the other person's. It is a particularly apt form for the assertion of male identity. One makes the other an object but retains possession of her or him. These are the structures of a master-slave relationship, which closely resemble that of romantic love. Hegel's discussion of the master-slave relationship explains how the need for recognition by another subject becomes a vehicle of domination. The two basic relationships with another (subject) are recognition and negation. Every action the subject performs on an object negates it. That is, it changes the object so that it is no longer itself, but something other than it was. In acting on things we change them; in transforming them, we are negating their old form. If we try to control them absolutely, we are taking away their form as things existing independently. We are thus completely negating them. If they continue to survive, not impervious to our act, but still recognizably themselves in their altered form, they are not completely negated. This is the goal a subject wants to achieve, to not completely negate the object, but this motive remains completely selfish.

The subject discovers that if it completely devours the other (at the animal level) or controls the other (at the human level), it can no longer get what it wanted from the other. So it learns better. But although the subject may relinquish the wish to control or devour the other completely, it does so only out of self-interest. This is a far cry from a real appreciation of the other's right to exist as a person in her or his own. (Hegel 145)

Rather than a tale of selfless love, Arjun and Preeti's relationship mirrors a master-slave relationship. The story that tugged at so many heart strings stems out of selfishness of one, and the acquiescence of other. A scene that perfectly encapsulates the master-slave relationship is when Arjun is graduating, and at the end of the semester they 
both have to part. Preeti incessantly requests Arjun to let her stay another night with him, so that they could leave together for their respective destinations. Arjun, on the other hand, wants her leave a day early, because he does not deal well with good-byes. Arjun doesn't really care for her wishes and ignores her pleas. Eventually her continuous pleading evokes his infamous anger, and he shouts at her. Preeti stays quiet, but in the end, slaps him. In response, Arjun smiles and apologizes for losing his temper. Preeti simply leaves for her bus at this reaction while being upset. Although, Arjun negates her wishes in favour of his own, he doesn't completely dominate her, and is visibly thrilled by her slap, giving an illusion of romantic love. The slap is an indication that his actions have affected her, but her decision to do so means that he has not completely negated her, that is, he can still derive the pleasure he wants.

\section{DEVDAS: THE SADO-MASOCHIST}

One of the most enduring icons of the Indian film cannon is the aristocratic, lovelorn, and ultimately tragic hero named Devdas. The pathos of this doomed hero effectively captured the hearts and the sympathy of the audience. Eric Barnouw and S. Krishnaswamy claim, "And virtually a generation wept over Devdas" (80). The Indian audience are so obsessed with the folklore, Devdas, that the recursive premise, the characters, sort of earn a cult following. A deeper analysis of the cult character reveals him to be a 'sado-masochist'. According to the logic of sado-masochism "one person maintains his boundary, and one allows the boundary to be broken" (Benjamin 285). Typically, the masculine tries to maintain the boundaries, while the feminine allows them to be broken. In Devdas the masculine and the feminine postures alternate. Devdas is perceived as heroic rather than pathetic because he has continually striven to demarcate the boundary between himself and the feminine.

Arjun Reddy tries to emulate the tell-tale elements of the iconic Devdas, in order to create the same understanding of the deep wounds afflicted by true love. Arjun Reddy, too, alternates between the traditional masculine and feminine posture of maintaining boundaries and allowing them to be broken down. It is Preeti, who we first see pining for Arjun, while he maintains his boundaries, and presents her with an ultimatum of six hours. If she doesn't come to him, he would then curse her "to marry a Tulu guy." These positions are switched in the climax of the film when, Arjun proposes to marry her, even though, he believes she is pregnant with another man's baby. It's interesting to note that while Arjun does let his boundaries get broken in this scene, he never fully lets go of control. Rather than approaching her with a sincere plea of his love, Arjun tells her to marry him because he knows she's not happy. When she questions him about how he can be so sure whether she's happy or not, he simply states that if he's not happy, she can't be happy either. He still remains in control of both their happiness. In fact, their coming together is a joint decision because while Preeti chooses to come back to him, he is the one who chooses to accept a baby who he believed was not his own.

The ability to renounce power, as the male masochists do, can be seen as a luxury belonging to those already empowered. (Modleski 149)

Being a woman, her character is under question, which means that she cannot afford to have a choice. Arjun grants Preeti the luxury of choice by being a generous man, who is obliging her by accepting the baby. It is Arjun who dictates the journey of their relationship through his decisions, throughout the film. Any power seemingly given to Preeti is simply illusory. While posing to be a hero as tragic as Devdas, Arjun is able to garner the sympathy of the audience. But all along, it is Arjun himself who holds the reins, and manages to create a happy-ending for him, too.

\section{CONCLUSION}

For a film that claims to be a new chapter in Telugu cinema, Arjun Reddy continues to preach the same regressive ideas in a more modern guise. It masquerades as a film with progressive ideals, but becomes a huge disservice to all such grand claims. The critic, Vishnupriya Bhandaram, writes, "Stripped off the cinematography, style and treatment, Arjun Reddy isn't that revolutionary after all, it is still a nod to the male ego." Not only is the film unsuccessful in its claims of challenging the age-old constructs of misogyny and toxic masculinity, it instead reinforces them. This becomes all the more harmful because they are being presented in a seemingly new, more liberal form. In their 2009 study analyzing the representation of relationships in top grossing romantic comedies, authors Johnson and Holmes found evidence to support the ideas of Social Cognitive Theory when they determined that people "look to relationships presented in film to learn what to expect from real-life relationships" (353). With the cult-like popularity of such a highly problematic film, it becomes important to ask several questions. Even though the film has generated discourse earlier unknown to the Telugu industry, is it justified in doing so? The film generates this discourse at the cost of not only normalization, but celebration of ideas like lack of consent and disrespect of authority. Did the film do more harm than good, with its thinly veiled misogyny being presented as new age feminism? Does Arjun Reddy glorify 
the very idea of toxic masculinity that it is trying to eradicate?

\section{REFERENCES}

[1] Vanga, Sandeep. (Director). (2017). Arjun Reddy [Film]. Bhadrakali Productions.

[2] Benjamin, J. (1980). The Bonds of Love: Rational Violence and Erotic Domination. Feminist Studies, 6(1), 144-174.

[3] Bhandaram, V. (2017, September 4). Arjun Reddy: How Vijay Devarakonda's Film is a Nod to Toxic Masculinity. Firstpost. https://www.firstpost.com/entertainment/arjunreddy-how-vijay-devarakondas-film-is-a-70mm-nod-totoxic-masculinity-4006083.html

[4] Collins, R. (1971). A Conflict Theory of Sexual Stratification. Social Problems, 19(1), 3-21.

[5] Hegel, G. W. F. (1952). The Independence and Dependence of Self-Consciousness: Master and Slave. The Phenomenology of Spirit. Hamburg: Felix Meiner.

[6] Jackson, S. (1995). Love: Complicity, Resistance and Change. Romance Revisited, 49.

[7] Johnson, K. R., \& Holmes, B. M. (2009). Contradictory Messages: A Content Analysis of Hollywood-Produced Romantic Comedy Feature Films. Communication Quarterly, 57(3), 352-373.

[8] Krishnaswamy, S., \& Barnouw, E. (1980). Indian Film (2nd ed.). Oxford U P.

[9] Modleski, T. (2014). Feminism Without Women: Culture and Criticism in a "Postfeminist" Age. Routledge.

[10] Mulvey, L. (1989). Visual Pleasure And Narrative Cinema. Visual and Other Pleasures (pp. 14-26). Palgrave Macmillan, London. 